Setyo Prabowo, Pranoto, Sri Budiastuti. (2019). Estimasi Emisi Gas Rumah Kaca yang Dihasilkan dari Tempat Pemrosesan akhir (TPA) di Jawa Tengah. Jurnal Bioeksperimen. Vol. 5 (1) Pp. 21-33. Doi: 10.23917/bioeksperimen. v5i1.2795

\title{
ESTIMASI EMISI GAS RUMAH KACA YANG DIHASILKAN DARI TEMPAT PEMROSESAN AKHIR (TPA) DI JAWA TENGAH
}

\author{
Setyo Prabowo ${ }^{1}$ Pranoto $^{2}$; Sri Budiastuti ${ }^{3}$ \\ ${ }^{1}$ Pascasarjana Ilmu Lingkungan \\ ${ }^{2}$ Fakultas Matematika dan Iilmu Pengetahuan Alam \\ ${ }^{3}$ Pascasarjana Ilmu Lingkungan \\ Universitas Sebelas Maret, Jl. Ir. Sutami 36 A Surakarta 57126 \\ Email : prabowiblh@gmail.com
}

\begin{abstract}
Abstrak
Penelitian ini perhitungan emisi Gas Rumah Kaca (GRK) pada sektor limbah padat domestik. Tujuan perhitungan ini adalah untuk memprediksi proyeksi emisi tanpa tindakan apa pun untuk mengurangi GRK, dan untuk menentukan target dan rencana aksi untuk menurunkan tingkat emisi pada 2010-2020. Perhitungan limbah padat domestik GRK ini didasarkan pada metode yang dikembangkan oleh IPCC pada tahun 2006. Salah satu faktor limbah padat yang berkontribusi terhadap peningkatan emisi GRK adalah landfill. Provinsi Jawa Tengah terdiri dari 35 kota / wilayah yang memiliki 57 tempat pembuangan sampah dengan kontrol landfill dan tipe open dumping. Komposisi TPA di Jawa Tengah adalah 9 TPA kontrol dan 48 Dumping Terbuka. Jenis limbah manajemen di TPA mendistribusikan perbedaan tingkat emisi. Pada 2010-2020 tingkat emisi yang dihasilkan oleh tipe kontrol TPA adalah 117,99 Gg $\mathrm{CO}_{2}$ e dan dengan pembuangan terbuka adalah $1948,18 \mathrm{Gg} \mathrm{CO}_{2}$ e. Hasil penelitian menyatakan bahwa mitigasi kemampuan pemerintah kota / daerah untuk menurunkan tingkat emisi pada pengembangan landfill pada tipe landfill kontrol adalah 9,35\%, sehingga untuk mengurangi tingkat emisi melalui limbah padat minimal dari sumber dengan 3R (Reduce, Reuse, Recycle) tindakan dan teknologi.
\end{abstract}

Kata kunci: Limbah Padat, TPA, GRK

\begin{abstract}
In this research Green House Gas (GHG) emission calculation on domestic solid waste sector. The puspose of this calculation is to predict emission projection without any action to reduce GHG, and to determine the target and action plan to decrease emision level at 2010-2020. This GHG domestic solid waste calculation base on an method which is develop by IPCC at 2006. One of many solid waste factor that contribute on the increase of emission GHG level is landfills. Central Java province consist of 35 city/region have 57 landfills with control landfill and open dumping type. The composition of landfills in Central Java is 9 Control landfill and 48 Open Dumping. The management waste type on landfill distribute difference level of emission. At 2010-2020 the emission level that produce by control landfill type is 117,99 $\mathrm{Gg} \mathrm{CO}_{2}$ e and by open dumping is $1948.18 \mathrm{Gg} \mathrm{CO}_{2}$ e. Base on result of this research, the capability mitigation action of city/region government to decrease emission level on landfills development at control landfill type is $9.35 \%$, so to decrease emission level trough solid waste minimize from the source with $3 R$ (Reduce, Reuse, Recycle) action and technology.
\end{abstract}

Keywords: Solid Waste, Landfill, GHG

\section{Pendahuluan}

Wilayah Provinsi Jawa Tengah berada pada $5^{0} 40^{\prime}$ - 8030' Lintang Selatan dan 108 $30^{\prime}$ - 111 $30^{\prime}$ Bujur Timur. Secara administratif wilayah Provinsi Jawa Tengah berbatasan dengan Samudera Hindia dan Provinsi Daerah Istimewa Yogyakarta di sebelah selatan; Provinsi Jawa Barat di sebelah barat; Provinsi Jawa Timur di sebelah timur, dan Laut
Jawa di sebelah utara. Provinsi Jawa Tengah terbagi menjadi 29 kabupaten dan 6 kota, dan terdiri dari 573 kecamatan yang meliputi 7810 desa dan 767 kelurahan dengan luas wilayah sebesar 3,254,412 Ha atau 25.04\% dari luas Pulau Jawa. Pertumbuhan jumlah penduduk di Jawa Tengah dari tahun ke tahun sebesar $0.01 \%$ akan berpengaruh pada jumlah timbulan sampah (Hezhong T, et al., 2013). Menurut Undang-Undang Nomor 18 tahun 2008 
tentang Pengelolaan Sampah, sampah adalah sisa kegiatan sehari-hari manusia dan/atau proses alam yang berbentuk padat. Sampah yang timbul dari aktivitas manusia telah menjadi salah satu masalah lingkungan utama dan menyebabkan pencemaran serta ancaman bagi kesehatan manusia (Vyas P, 2011).

Keberadaan sampah tidak hanya mengganggu sanitasi tetapi juga berpengaruh pada perubahan iklim. Wilayah Jawa Tengah tidak luput dari dampak perubahan iklim. Penyebab dari perubahan iklim tidak lain dikarenakan keberadaan emisi Gas Rumah Kaca. GRK merupakan gas-gas yang memiliki efek rumah kaca, seperti gas Karbon Dioksida $\left(\mathrm{CO}_{2}\right)$, Metana $\left(\mathrm{CH}_{4}\right)$, Dinitrogen Mono Oksida $\left(\mathrm{N}_{2} \mathrm{O}\right)$, Hidro Fluorocarbon (HFCs), Sulfur Hexaflorida (SF) dan Perfluoro Karbon (PFCs) (KLHK, 2012). Beberapa gas tersebut memiliki efek rumah kaca lebih besar daripada gas lainnya. Sebagai contoh, gas $\mathrm{CH}_{4}$ memiliki efek 25 kali lebih besar dibanding dengan gas $\mathrm{CO}_{2}$ (Solomon et al., 2007).

Tempat Pemrosesan Akhir (TPA) merupakan tempat dimana sampah mencapai tahap terakhir dalam pengelolaannya sejak mulai dihasilkan pada sumber, pemilahan, pewadahan, pengumpulan, pemindahan/pengangkutan, pengolahan. TPA merupakan tempat dimana sampah diisolasi secara aman agar tidak menimbulkan gangguan terhadap lingkungan sekitarnya dan merupakan upaya akhir. Hasil penelitian terbaru di lokasi TPA yang dilakukan di Kota Pekalongan tahun 2013 oleh GIZ, komposisi jenis sampah sebagian besar berupa sampah organik yakni sebesar $61,37 \%$ yang akan mengalami proses dekomposisi secara anaerobik menjadi gas $\mathrm{CH}_{4}, \mathrm{CO}_{2}$, dan sejumah kecil gas $\mathrm{N}_{2}, \mathrm{H}_{2}, \mathrm{H}_{2} \mathrm{~S}, \mathrm{H}_{2} \mathrm{O}$. Contoh reaksi di bawah ini menunjukkan proses dekomposisi secara aerobik dan anaerobik. Pada kondisi aerobik (reaksi yang terjadi pada proses pengomposan) tidak dihasilkan $\mathrm{CH}_{4}$. Sebaliknya, pada kondisi anaerobik (reaksi yang terjadi di dalam TPA), satu mol organik dikonversi menjadi tiga mol $\mathrm{CH}_{4}$ dan jumlah produksi $\mathrm{CO}_{2}$ adalah sama untuk kedua kondisi tersebut (Suprihatin.dkk, 2008). Berikut reaksi dekomposisi sampah secara aerobik dan anaerobik :
(i) Bahan organik $\longrightarrow \mathrm{CO}_{2}+\mathrm{H}_{2} \mathrm{O}$ (kondisi aerobik)

(ii) Bahan organik $\longrightarrow \mathrm{CO}_{2}+\mathrm{CH}_{4}$ (kondisi anaerobik)

Gas $\mathrm{CH}_{4}$ adalah salah satu gas rumah kaca utama, kedua setelah gas $\mathrm{CO}_{2}$ dalam kontribusinya terhadap pemanasan global. Konsentrasi gas $\mathrm{CH}_{4}$ di atmosfer telah meningkat sekitar $0,6 \%$ per tahun dan memiliki lebih dari dua kali lipat selama dua abad terakhir. $\mathrm{CH}_{4}$ merupakan salah satu GRK yang memiliki peran penting di atmosfer namun juga sebagai pencemar lingkungan. Gas $\mathrm{CH}_{4}$ merupakan komponen utama dari gas alam yang dapat menjadi sumber energi yang berharga. Dikarenakan gas $\mathrm{CH}_{4}$ adalah sumber energi dan GRK, maka mengurangi emisi gas $\mathrm{CH}_{4}$ dari TPA secara ekonomi akan menguntungkan. Sebaliknya, konsentrasi atmosfer gas $\mathrm{CO}_{2}$ meningkat sekitar $0.4 \%$ per tahun. Gas $\mathrm{CH}_{4}$ memiliki masa tinggal di atmosfer lebih singkat daripada gas rumah kaca lainnya yakni sekitar 11 tahun di atmosfer, sedangkan gas $\mathrm{CO}_{2}$ masa tinggalnya sekitar 120 tahun. Karena gas $\mathrm{CH}_{4}$ memiliki tingkat bahaya 21 kali lebih besar dari pada gas $\mathrm{CO}_{2}$ dan masa tinggal di atmosfer relatif pendek maka stabilisasi gas $\mathrm{CH}_{4}$ akan berdampak langsung pada perubahan iklim (Mark Orlic and Tom Kerr, 1996). Perlu diketahui bahwa emisi gas $\mathrm{CO}_{2}$ yang dihasilkan berasal dari sumber alam (misal makanan, kebun, kertas dan limbah kayu) yang terjadi di TPA tidak dipertimbangkan sebagai emisi GRK karena sebagai biogenik (Jensen and Pipatti, 2002).

Menurut Karagiannidis et al (2007), produksi gas $\mathrm{CH}_{4}$ di TPA biasanya dimulai 6 s.d 12 bulan setelah sejak ditempatkan, kemudian meningkat hingga maksimum sesaat setelah penutupan TPA dannsecara bertahap menurun selama periode 3050 tahun. Menurut Tchobanoglous et al., (1993) 1 ton sampah domestik dapat memproduksi hingga $300 \mathrm{~m}^{3}$ biogas dan biogas yang utama terdiri dari gas $\mathrm{CH}_{4}, \mathrm{CO}_{2}$ dengan konsentrasi gas $\mathrm{CH}_{4}$ pada biogas sebesar 35-60\%.

Menurut Sudrajat (2006), tipe TPA di Indonesia saat ini baru ada 2, yakni sistem urug terkendali (control landfill) dan tanpa urug (open dumping), kedua tipe tersebut juga terdapat di wilayah Jawa Tengah. Jumlah TPA di Jawa Tengah dipastikan lebih dari 35 lokasi mengingat 1 Kabupaten dapat memiliki TPA lebih dari 1 lokasi. Ketersediaan informasi data pengelolaan 
sampah domestik seperti tipe TPA, jumlah sampah terangkut, pola distribusi pengelolaan sampah, komposisi sampah sangat sulit diperoleh dan sering kali menyebabkan banyak kalangan kesulitan untuk menghitung besarnya emisi GRK sampah domestik (Bappenas, 2016).

Kondisi TPA di Jawa Tengah diperkirakan sebagian besar masih menggunakan sistem open dumping yang akan berkontribusi sebagai penyumbang emisi gas $\mathrm{CH}_{4}$ yang cukup besar. Sebagai bentuk upaya mendukung Pemerintah Indonesia yang sudah berkomitmen menurunkan emisi s.d. 2020 oleh Mantan Presiden Susilo Bambang Yudoyono, maka perlu ditetapkan target penurunan emisi GRK sektor sampah (TPA) di wilayah Jawa Tengah. Sebelum menetapkan target penurunan emisi GRK, maka perlu dilakukan perhitungan emisi tanpa adanya kegiatan penurunan yang kita sebut dengan istilah BAU (Businness as Usual) dengan tahun dasar mulai 2010. Untuk melakukan perhitungan BAU diperlukan datadata sampah terangkut, pola distribusi pengelolaan sampah, jenis pengelolaan sampah di TPA (Bappenas, 2016). Pedoman yang digunakan untuk menghitung adalah Pedoman Penyelenggaraan Inventarisasi Gas Rumah Kaca Sektor Limbah (KLH, 2012).

Penelitian ini ingin melihat : 1) bagaimana pengaruh pengelolaan sampah di TPA terhadap emisi GRK di Jawa Tengah? dan 2) Jenis pengelolaan sampah yang berkontribusi pada penurunan emisi GRK dan berapa capaian penurunan emisi GRK s.d. tahun 2020.

Penelitian bertujuan untuk menganalisis pengaruh pengelolaan sampah di TPA terhadap emisi GRK di Jawa Tengah; 2) mengkaji besarnya emisi GRK yang terbentuk di TPA tahun 20102020

\section{Material dan Metode}

Penelitian ini dilakukan di 35 Kabupaten/ Kota Provinsi Jawa Tengah. Penelitian dilaksanakan pada Tanggal 18 Januari 2017 sampai 21 Juni 2017.

Sampel yang digunakan mencakup proyeksi penduduk tahun 2010-2020, sistem pengelolaan sampah, karakteristik dan komposisi sampah di TPA, jumlah timbulan sampah yang dihasilkan, jumlah sampah terangkut.
Teknik Pengumpulan Data dilakukan melalui pengumpulan sampel/data primer maupun sekunder melalui kuisionier, data sampling, observasi lapangan, dan indepth interview.

\section{Tahapan Penelitian}

Identifikasi sumber penghasil emisi GRK subsektor sampah dilakukan untuk mendapatkan gambaran tentang pengenalan kegiatan yang mempengaruhi emisi GRK. Identifikasi dimaksud meliputi berikut.

1. Komposisi jenis sampah di TPA. Terdapat 11 jenis sampah yang diperlukan untuk menentukan laju pembentukan emisi $\mathrm{CH}_{4}$. Data komposisi sampah di TPA dengan jumlah 11 komponen baru tersedia di Palembang dan Medan yang merupakan hasil pendataan yang dilakukan oleh KLH bekerja sama dengan JICA tahun 2011 (KLHK, 2015) dan di Kota Pekalongan tahun 2013 (GIZ, 2013).

2. Jumlah sampah yang dihasilkan tahun 2010-2020.

Jumlah sampah diperoleh melalui proyeksi penduduk oleh BPS yang dikalikan dengan jumlah sampah yang dihasilkan per kapita.

3. Jumlah sampah yang terangkut ke TPA dan sistem pengelolaan sampah di TPA. Jumlah sampah yang terangkut di TPA tahun 2010 digunakan untuk mengetahui prosentase sampah yang terolah di TPA dan digunakan sebagai tahun dasar untuk menghitung besarnya emisi dihasilkan mulai tahun 2010. Sistem pengelolaan sampah di TPA berdasarkan pedoman dari IPCC 2006 dapat diklasifikasikan sebagai berikut.

a. Terkelola dengan baik - anaerob (Sanitary Landfill) : memiliki sistem penempatan sampah yang baik (sel khusus), kontrol terhadap pemulung, dilakukan penutupan secara rutin dengan tanah penutup, kompaksi secara mekanis.

b. Terkelola dengan baik - semi aerob (Control Landfill) : memiliki sistem penempatan sampah yang baik (sel khusus), tanah penutup, sistem 
penyaluran lindi, struktur pondasi, dan sistem ventilasi.

c. Tidak terkelola/tanpa pengurugan (Umanaged Deep/Open Dumping) kondisi anaerobik. TPA jenis ini memiliki ketinggian $>5 \mathrm{~m}$.

d. Tidak terkelola/ tanpa pengurugan (Unmanaged Shallow/Open Dumping) kondisi aerobik. TPA jenis ini memiliki ketinggian $<5 \mathrm{~m}$

e. Tidak terkategori: TPA liar/ tidak terkontrol dengan kriteria dibuang ke sungai, dikubur.

\section{Identifikasi pola pengelolaan sampah di masyarakat}

Pola pengelolaan sampah dapat diketahui berdasarkan hasil penelitian yang dilakukan oleh Pemerintah Kabupaten/Kota pada tahun 2010-2013 melalui Program Percepatan Sanitasi Permukiman (PPSP). Data pengelolaan sampah di masyarakat diperoleh di Kabupaten/Kota untuk mengetahui pengelolaan sampah selain dengan TPA.

\section{a. Perhitungan BAU Emisi GRK}

Pehitungan BAU emisi GRK menggunakan referensi dari Bappenas yakni Pedoman Teknis Perhitungan Baseline Emisi GRK Sektor Pengolahan Limbah yang mengadopsi dari standar perhitungan IPCC (Bappenas, 2016) berupa kalkulator excel. Perhitungan BAU untuk mengetahui besarnya emisi GRK yang dihasilkan tanpa adanya kegiatan mitigasi/penurunan emisi. Pedoman ini bertujuan untuk memperkirakan jumlah emisi GRK dengan metodologi yang disepakati secara internasional. Model perhitungan IPCC 2006 telah digunakan di banyak negara berkembang (Weitz et al., 2008), (Wangyao et al., 2009). Prinsip perhitungan IPCC 2006 sektor sampah domestik dibagi menjadi beberapa kategori sebagai berikut.

1) Pembuangan sampah padat (Solid Waste Disposal);

Kegiatan ini mencakup pembuangan sampah ke TPA (Managed Disposal Site), penumpukan sampah di tanah terbuka/lahan kosong (Unmanaged Disposal Site), dan pembuangan sampah di sungai, penguburan sampah (Uncategorized).

Menghitung total sampah terurai yang ditimbun di TPA dengan persamaan sebagai berikut.

\section{$\mathrm{DDOC}_{\mathrm{m}}=\mathrm{W}^{*} \mathrm{DMC}^{*} \mathrm{DOC}^{*} \mathrm{DOCf}^{*}$ ${ }^{*} \mathrm{MCF}$}

\section{Dimana.}

${ }_{\text {DDOC }} \mathrm{m}$ : Total sampah terurai yang ditimbun di TPA, Gg

W : Total sampah yang ditimbun di TPA, Gg

DOC : Fraksi sampah mudah terurai, Gg C/Gg sampah

DOCf : Fraksi DOC teterdekomposisi

MCF : Faktor koreksi $\mathrm{CH}_{4}$ untuk dekomposisi aerob di TPA sebelum kondisi anaerob terbentuk

Potensi dihasilkannya gas $\mathrm{CH}$ dari sampah yang ditimbun di TPA dapat dihitung dengan persamaan sebagai berikut.

$\mathrm{Lo}=\mathrm{DDOC}_{\mathrm{m}} * \mathrm{~F}^{*} 16 / 12$

Dimana.

Lo : Potensi emisi $\mathrm{CH}_{4} \mathrm{Gg}$

$\mathrm{F} \quad$ : Fraksi emisi $\mathrm{CH}_{4}$ yang dihasilkan di TPA

16/12 : Rasio berat molekul $\mathrm{CH}_{4} / \mathrm{C}$

\section{Hasil dan Pembahasan}

\section{Komposisi Sampah}

Komposisi sampah diperlukan untuk menentukan Degradable Organic Carbon (DOC) akan berpengaruh pada tingkat emisi $\mathrm{CH}_{4}$ yang dihasilkan sampah. Pada setiap sampah biasanya besarnya DOC tergantung pada komposisi (\% berat) 
dan Dry Matter Content/DMC (kandungan berat kering). Idealnya komposisi sampah di TPA diukur pada masing-masing TPA. Namun keterbatasan anggaran maka dapat menggunakan hasil survey yang dilakukan oleh KLH di TPA Medan, Palembang pada tahun 2011 dan hasil survey yang dilakukan GIZ di Kota Pekalongan tahun 2013. Pada penelitian ini penulis menggunakan data komposisi sampah Kota Pekalongan yang mana pola konsumsi masyarakat di Kabupaten/Kota lainnya tidak jauh berbeda dengan yang dihasilkan di Kota Pekalongan daripada menggunakan data komposisi sampah di Medan dan Palembang. Berikut gambar 1 data komposisi sampah di TPA Kota Pekalongan :

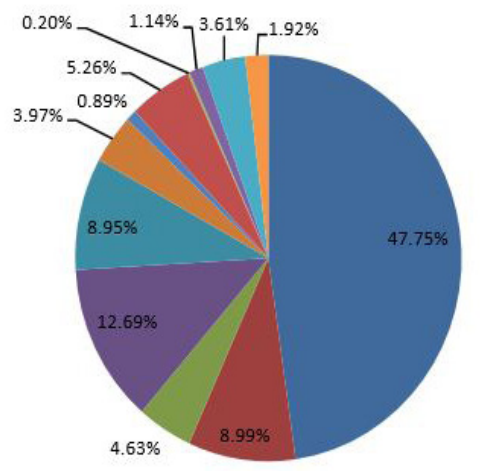

m Sampah Dapur - Daun Tanaman = Kayu n Plastik

Grafik 1. Komposisi Sampah

Berdasarkan gambar di atas, komposisi sampah dapur tetap yang tertinggi diantara sampah lainnya yakni $47,75 \%$, hal ini mengingat sampah dapur/makanan dihasilkan dari sisa kebutuhan sehari-hari dari rumah tangga, pasar dan restoran/warung.

\section{Degradable Organic Carbon (DOC)}

Karakteristik yang akan menentukan laju pembentukan emisi gas $\mathrm{CH}_{4}$ pada proses degradasi komponen organik/karbon pada sampah adalah DOC. Angka DOCi tiap jenis komponen sampah di Indonesia belum ada penelitian sehingga penulis merujuk pada angka default IPCC 2006. Komponen sampah yang mengandung DOC adalah makanan, kertas, pembalut/nappies, kayu, kain/tekstil, karet\&kulit. DOC merupakan hasil perkalian antara DOCi dengan komposisi sampah di
TPA. Berikut tabel 1 hasil perhitungan DOC dari sampah yang dihasilkan :

Tabel 1 Degradable Organic Carbon (DOC)

\begin{tabular}{clc}
\hline No & Jenis Sampah & Nilai DOC \\
\hline 1 & Makanan & 0,216 \\
2 & Kertas,Pembalut & 0,041 \\
3 & Kayu & 0,025 \\
4 & Kain & 0,016 \\
5 & Karet\&Kulit & 0,003 \\
6 & Plastik & 0,000 \\
7 & Logam & 0,000 \\
8 & Kaca & 0,000 \\
\hline \multicolumn{2}{c}{ Sumber : hasil perhitungan, 2017 }
\end{tabular}

\section{Fraksi DOC Terdekomposisi ( DOC $\left._{\mathrm{f}}\right)$}

Selain DOC, fraksi DOC $_{f}$ yang dapat terkomposisi pada kondisi anaerobik perlu diketahui. Fraksi DOC $_{f}$ terdekomposisi adalah estimasi fraksi DOC yang mengalami dekomposisi di TPA, hal ini disebabkan tidak semua senyawa karbon organik pada sampah dapat dengan mudah terurai atau terurai secara lambat pada kondisi anaerob. Nilai $\mathrm{DOC}_{\mathrm{f}}$ yang umum digunakan adalah 0,5 (IPCC 2006).

\section{Fraksi Emisi $\mathrm{CH}_{4}$ yang dihasilkan di TPA (simbol F)}

Sampah yang terdapat di TPA akan menghasilkan gas dengan komposisi $\mathrm{CH}_{4}$ sebesar $50 \%$. Komposisi sampah yang didominasi oleh minyak (fat and oil) dalam jumlah besar akan memiliki fraksi emisi gas $\mathrm{CH}_{4}$ lebih besar dari $50 \%$. Hal ini yang menjadikan angka 50\% sebagai data default (IPCC, 2006).

\section{Faktor Koreksi $\mathrm{CH}_{4} /$ Methana Correction Factor (MCF)}

Setiap TPA memiliki sistem pengelolaan yang berbeda-beda, faktor koreksi $\mathrm{CH}_{4}$ ini menunjukkan bahwa TPA terbuka (Open Dumping) akan menghasilkan gas $\mathrm{CH}_{4}$ yang lebih sedikit dibandingkan TPA yang terkelola dengan baik. Hal ini disebabkan pada TPA terbuka, sampah yang terletak pada bagian atas akan mengalami dekomposisi secara aerobik. Nilai MCF terdiri dari 4 kategori yang disajikan pada Tabel 2 berikut. 
Tabel 2. Faktor Koreksi CH

\begin{tabular}{clc}
\hline No & \multicolumn{1}{c}{ Tipe TPA } & Nilai MCF \\
\hline 1 & TPA Sanitary Landfill & 1,0 \\
2 & TPA Control Landfill & 0,5 \\
3 & TPA Open Dumping $>5 \mathrm{mtr}$ & 0,8 \\
4 & TPA Open Dumping $<5 \mathrm{mtr}$ & 0,4 \\
& TPA Liar (pembuangan \\
5 & sampah di sungai, penguburan \\
& sampah)/ (Uncategorized). \\
\hline \multicolumn{3}{c}{ Sumber : IPCC, 2006 }
\end{tabular}

Untuk diketahui bahwa pengelolaan sampah apabila dilakukan dengan sistem sanitary landfill akan menghasilkan $\mathrm{CH}_{4}$ lebih besar dibandingkan dengan sistem open dumping. Namun apabila gas $\mathrm{CH}_{4}$ yang dihasilkan melalui sanitary landfill dapat dimanfaatkan sebagai energi maka dianggap tidak ada $\mathrm{CH}_{4}$ yang diemisikan. Hal ini berbeda dengan emisi yang dihasilkan dari sistem open dumping yang memiliki dampak lebih kecil $\mathrm{CH}_{4}$ dibandingkan sanitary landfill. Namun pada kondisi open dumping sulit dilakukan penangkapan $\mathrm{CH}_{4}$ mengingat tidak terdapat konstruksi yang jelas dari TPA dan dampak yang ditimbulkan dapat menyebabkan kerusakan lingkungan, sedangkan sesuai guideline IPCC 2006 bahwa pengelolaan sampah dengan cara dibuang ke sungai dan dikubur termasuk dalam kategori pengelolaan TPA liar/uncaterogized.

\section{Pola Pengelolaan Sampah}

Berdasarkan hasil inventarisasi TPA di 35 Kabupaten/Kota, terdapat 57 TPA yang digunakan untuk memproses sampah. Dari ke 57 TPA belum ada yang menggunakan sistem sanitary landfill dan umumnya masih menggunakan pemrosesan sistem controll landfill dan open dumping.

Tabel 3. Pola Pengelolaan Sampah

\begin{tabular}{clc}
\hline No & \multicolumn{1}{c}{ Pola Pengelolaan Sampah } & $\mathbf{\%}$ \\
\hline 1 & Unmanaged Shallow/TPA open dumping $<5 \mathrm{mtr}$ & 0,58 \\
2 & Unmanaged Deep/TPA open dumping $>5 \mathrm{mtr}$ & 10,78 \\
3 & Control landfill & 2,11 \\
4 & Sanitary landfill & 0,00 \\
5 & Dikubur/Uncategory & 9,71 \\
6 & Dibuang ke sungai/Uncategory & 9,18 \\
7 & Dibiarkan saja & 5,49 \\
8 & Dibuang ke lahan kosong & 15,79 \\
9 & Dibakar & 41,41 \\
10 & Lain-lain & 4,95 \\
\hline \multicolumn{2}{c}{ Sumber : hasil pengolahan data, 2017 }
\end{tabular}

Selain dikelola di TPA, juga terdapat aktivitas lain pengelolaan sampah di masyarakat yang merupakan hasil identifikasi program PPSP tahun 2010-2013 dari 35 Kabupaten/Kota (Tabel 3).

Berdasarkan tabel di atas, penulis akan mengitung besarnya emisi yang dihasilkan dari kegiatan TPA yakni open dumping (unmanaged shallow, unmanaged deep) dan control landfill. Menurut IPCC 2006, kategori unmanaged shallow meliputi sampah yang dibuang di TPA dengan kondisi terbuka ketebalan sampah < $5 \mathrm{mtr}$, sampah dibuang di lahan kosong dan dibiarkan saja dengan total unmanaged shallow sebesar $21,59 \%$.

\section{Timbulan sampah 2010-2020}

Guna mengetahui pengaruh sampah terhadap terbentuknya emisi GRK, maka perlu dihitung jumlah timbulan sampah yang dihasilkan tahun 2010-2020 melalui proyeksi penduduk dari BPS (Bappenas, 2016) yakni jumlah timbulan sampah yang dihasilkan per kapita sebesar 0.25 ton. Berikut tabel 4 dan grafik 1 proyeksi jumlah penduduk dan jumlah timbulan sampah di TPA tahun 2010-2020. 
Tabel 4 Jumlah Timbulan Sampah

\begin{tabular}{ccccc}
\hline \multirow{2}{*}{ Tahun } & \multirow{2}{*}{$\begin{array}{c}\text { Jumlah Penduduk } \\
\text { (Jiwa) }\end{array}$} & \multicolumn{3}{c}{ Jumlah Pengelolaan Sampah (Gg/tahun) } \\
\cline { 3 - 5 } & 32.382 .657 & 192,78 & 855,56 & Control \\
Landfill & Unmanaged Deep & Unmanaged Shallow \\
\hline 2010 & 32.643 .612 & 194,33 & 862,46 & 1719,89 \\
2011 & 33.270 .207 & 198,06 & 879,01 & 1733,75 \\
2012 & 33.264 .339 & 198,03 & 878,86 & 1767,03 \\
2013 & 33.522 .663 & 199,57 & 885,68 & 1766,72 \\
2014 & 33.774 .100 & 201,06 & 892,33 & 1780,44 \\
2015 & 34.019 .100 & 202,52 & 898,80 & 1793,79 \\
2016 & 34.257 .900 & 203,94 & 905,11 & 1806,80 \\
2017 & 34.490 .800 & 205,33 & 911,26 & 1819,49 \\
2018 & 34.718 .200 & 206,68 & 917,27 & 1831,85 \\
2019 & 34.940 .100 & 208,01 & 923,13 & 1843,93 \\
2020 & & Sumber : Hasil perhitungan, 2017 & 1855,72 \\
\hline
\end{tabular}

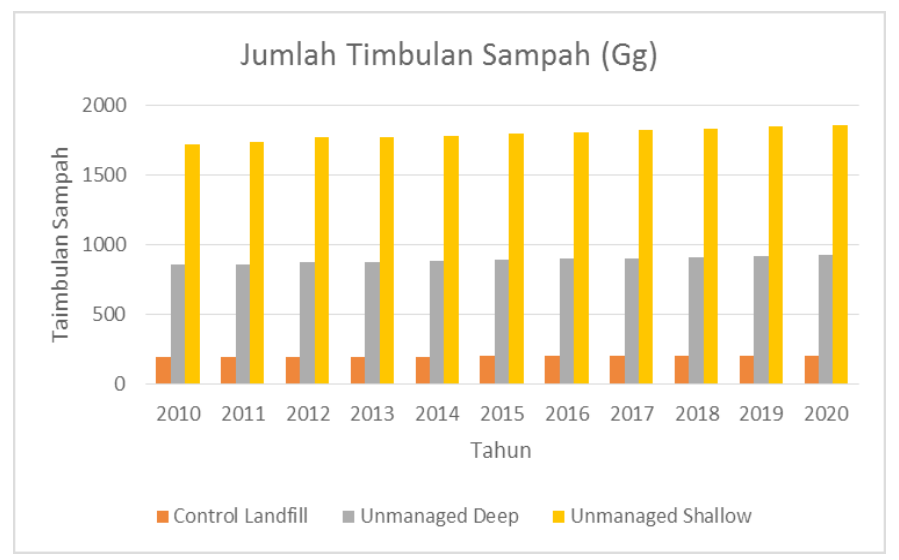

Grafik 2. Jumlah Timbulan Sampah

Berdasarkan grafik 2 di atas, jumlah sampah yang dikelola melalui TPA open dumping tipe unmanaged shallow lebih banyak dibandingkan dengan TPA tipe control landfill maupun TPA open dumping tipe unmanaged deep. Hasil dari identifikasi jumlah TPA sebanyak 57 menunjukkan tipe unmanaged deep sebesar $77.19 \%$, tipe unmanaged shallow sebesar $7.01 \%$ dan tipe control landfill sebesar $15.79 \%$. Kondisi ini sama juga terjadi di negara berkembang lainnya bahwa tipe TPA unmanaged deep sebesar $58.3 \%$ (Kyiv, 2004).

\section{Businness as Usual (BAU) Emisi GRK}

1. BAU Emisi GRK dari TPA Open Dumping Tipe Unmanaged Shallow

TPA open dumping tipe unmanaged shallow merupakan kondisi TPA open dumping dengan ketebalan sampah $<5$ mtr mulai dari dasar s.d. permukaan atas sampah. Data ketebalan sampah di TPA diperoleh berdasarkan quisonier yang dibagikan ke instansi yang menangani kebersihan Kabupaten/Kota sekaligus dilakukan peninjauan langsung di lapangan. Dengan menggunakan Kalkulator Excel resmi dari Bappenas, maka jumlah emisi dari TPA unmanaged shallow dapat diketahui. Perlu diketahui pada pengelolaan sampah di TPA hanya mengemisikan $\mathrm{CH}_{4}(\mathrm{KLH}, 2012)$. TPA open dumping tipe unmanaged shallow memiliki prinsip pengelolaan sampah dengan tumpukan terbuka, tanpa ada pemadatan, dan tidak memenuhi persyaratan teknis TPA. Ketebalan sampah akan mempengaruhi pembentukan $\mathrm{CH}_{4}$ melalui perbedaan akses udara dan kepadatan sampah. Sampah dengan ketebalan $<5 \mathrm{~m}$ umumnya membusuk secara aerobik, menghasilkan sedikit gas $\mathrm{CH}_{4}$ (IPCC 1996). Besarnya MCF TPA open dumping tipe unmanaged shallow adalah 0,4. Berikut tabel 5 besarnya emisi gas $\mathrm{CH}_{4}$ atau $\mathrm{CO}_{2} \mathrm{e}$ yang dihasilkan dari tipe unmanaged shallow. 
Tabel 5. Emisi Tipe Unmanaged Shallow

\begin{tabular}{ccc}
\hline \multirow{2}{*}{ Tahun } & \multicolumn{2}{c}{ Jumlah Emisi } \\
\cline { 2 - 3 } & Gg CH$_{4}$ & Total Gg CO_eq \\
\hline 2010 & 36,34 & 763,07 \\
2011 & 37,12 & 779,52 \\
2013 & 37,88 & 795,49 \\
2014 & 38,73 & 813,24 \\
2015 & 39,43 & 828,09 \\
2016 & 40,12 & 842,42 \\
2017 & 40,77 & 856,20 \\
2018 & 41,40 & 869,44 \\
2019 & 42,01 & 882,14 \\
2020 & 42,59 & 894,34 \\
& 43,15 & 906,07 \\
\hline
\end{tabular}

Sumber : Hasil perhitungan, 2017

Pada tabel di atas merupakan total hasil perhitungan seluruh jenis sampah yang berpengaruh pada terbentuknya emisi $\mathrm{CH}_{4}$. Dengan menggunakan tool kalkulator excel Bappenas, maka dapat diketahui besarnya emisi yang dihasilkan dari TPA open dumping tipe unmanaged shallow s.d. tahun 2020 untuk gas $\mathrm{CH}_{4}$ sebesar $43,15 \mathrm{Gg}$ atau sebesar 906,07 $\mathrm{Gg} \mathrm{CO}_{2} \mathrm{e}$.

\section{BAU Emisi GRK dari TPA Open}

\section{Dumping Tipe Unmanaged Deep}

TPA open dumping tipe unmanaged deep merupakan kondisi TPA dengan ketebalan sampah $>5 \mathrm{mtr}$ mulai dari dasar s.d. permukaan atas sampah.
Produksi gas $\mathrm{CH}_{4}$ lebih banyak dikarenakan lapisan sampah di bagian atas mencegah akses udara ke lapisan bawah menciptakan kondisi anaerobik (Kyiv, 2004). Besarnya MCF open dumping tipe unmanaged deep adalah 0,8. Jumlah emisi yang dihasilkan dari tipe unmanaged deep lebih besar daripada Unmanaged Shallow. Sebagai contoh hasil perhitungan dari tipe unmanaged deep dan unmanaged shallow pada tahun 2020 masingmasing sebesar 901,45 $\mathrm{Gg} \mathrm{CO}_{2}$ eq dan 906,07 Gg $\mathrm{CO}_{2}$ eq. Berikut tabel 6 .hasil perhitungan jumlah emisi yang dihasilkan dari TPA open dumping tipe unmanaged deep

Tabel 5 Emisi Tipe Unmanaged Deep

\begin{tabular}{ccc}
\hline \multirow{2}{*}{ Tahun } & \multicolumn{3}{c}{ Jumlah Emisi } \\
\cline { 2 - 3 } & Gg CH$_{4}$ & Total Gg CO, eq \\
\hline 2010 & 36,15 & 759,18 \\
2011 & 36,93 & 775,55 \\
2012 & 37,69 & 791,43 \\
2014 & 38,53 & 809,10 \\
2015 & 39,23 & 823,88 \\
2016 & 39,91 & 838,13 \\
2017 & 40,56 & 851,84 \\
2018 & 41,19 & 865,01 \\
2019 & 41,79 & 877,65 \\
2020 & 42,37 & 889,79 \\
& 42,93 & 901,45 \\
\hline
\end{tabular}




\section{BAU Emisi GRK dari TPA Control Landfill}

Pengelolaan sampah dengan TPA control landfill merupakan pengelolaan sampah dengan sistem pengurugan sampah dengan media tanah/ lapisan plastik sekurang-kurangnya 7 hari sesuai Permen PU No. 3 Tahun 2013. TPA control landfill dirancang khusus untuk dengan desain teknis yang tepat, yang memungkinkan pengelolaan sampah yang terkontrol. Pengelolaan sampah yang baik memastikan bahwa sampah dipadatkan untuk meminimalkan penggunaan ruang hampa. Semua faktor ini dapat mendorong perkembangan dan pemeliharaan kondisi anaerobik yang cepat di dalam TPA dan dapat dimanfaatkan gas $\mathrm{CH}_{4}$ yang dihasilkan (Kyiv, 2004). jumlahnya pengelolaan sampah di Kabupaten/Kota hanya dengan sistem control landfill sangat sedikit dibandingkan yang dikelola tanpa gunakan media urug (open dumping). Emisi yang dihasilkan dari sistem control landfill lebih sedikit dibandingkan dengan sistem unmanaged deep dan shallow.

Tabel 6 Emisi Tipe Control Landfill

\begin{tabular}{ccc}
\hline \multirow{2}{*}{ Tahun } & \multicolumn{3}{c}{ Jumlah Emisi } \\
\cline { 2 - 3 } & $\mathbf{G g ~ C H}_{4}$ & Total Gg CO $\mathbf{2 q}$ \\
\hline 2010 & 4,76 & 99,89 \\
2011 & 4,85 & 101,95 \\
2012 & 4,95 & 103,96 \\
2013 & 5,06 & 106,21 \\
2014 & 5,15 & 108,09 \\
2015 & 5,23 & 109,90 \\
2017 & 5,32 & 111,65 \\
2018 & 5,40 & 113,33 \\
2019 & 5,47 & 114,94 \\
2020 & 5,55 & 116,49 \\
& 5,62 & 117,99 \\
\hline
\end{tabular}

Dari perhitungan-perhitungan sebelumnya, jumlah emisi yang dihasilkan dari pengelolaan sampah tipe open dumping unmanaged deep dan shallow lebih besar dibandingkan dengan control landfill. TPA control landfill tetap mengemisikan gas $\mathrm{CH}_{4}$ dikarenakan tidak semua sampah mengalami pembusukan sempurna, sesuai IPCC 2006 bahwa MCF control landfill sebesar 0,5. Berikut tabel 7 dan gambar yang menyajikan data total TPA tipe open dumping/unmanaged (unmanaged deep dan unmanaged shallow) dengan TPA control landfill.

Tabel 7 Emisi Tipe Unmanaged dan Control Landfill

\begin{tabular}{cccc}
\hline \multirow{2}{*}{ Tahun } & \multicolumn{2}{c}{ Emisi GRK $\left(\mathbf{C O}_{2} \mathbf{e}\right) \mathbf{G g}$} & \multirow{2}{*}{ Total Emisi $\left(\mathbf{C O}_{\mathbf{2}} \mathbf{e}\right) \mathbf{G g}$} \\
\cline { 2 - 3 } & Unmanaged & Control Landfill & 1641,23 \\
2010 & 1541,34 & 99,89 & 1676,52 \\
2011 & 1574,57 & 101,95 & 1710,78 \\
2012 & 1606,82 & 103,96 & 1748,89 \\
2013 & 1642,68 & 106,21 & 1780,77 \\
2014 & 1672,68 & 108,09 & 1811,52 \\
2015 & 1701,62 & 109,90 & 1841,11 \\
2016 & 1729,46 & 111,65 & 1869,52 \\
2017 & 1756,19 & 113,33 & 1896,79 \\
2018 & 1781,85 & 114,94 & 1922,99 \\
2019 & 1806,50 & 116,49 & 1948,18 \\
2020 & 1830,19 & 117,99 & \\
\hline
\end{tabular}

Sumber : Hasil perhitungan, 2017 


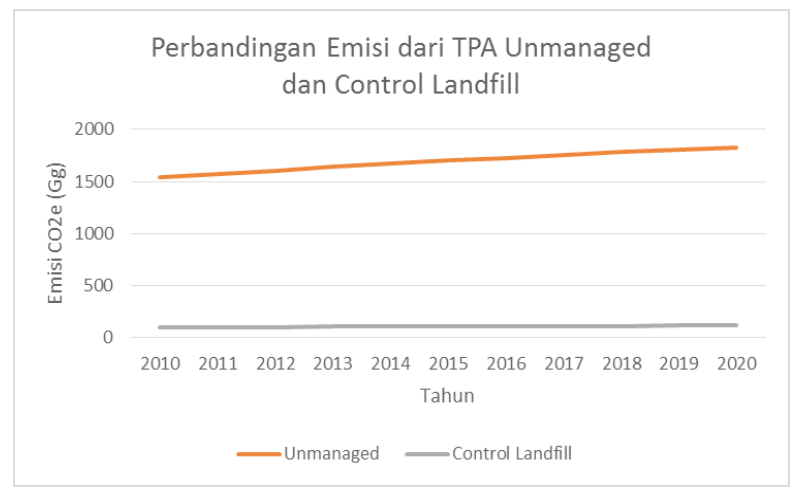

Grafik 3. Perbandingan emisi dari TPA Unmanaged dan Control Landfill

Berdasarkan perhitungan di atas, emisi yang dihasilkan dari TPA tipe unmanaged dan control landfill menunjukkan perbedaan yang signifikan jumlahnya. Emisi yang dihasilkan dari TPA tipe Control Landfill hanya 5,90 \% dari total emisi dari TPA, sedangkan emisi dari TPA tipe unmanaged/ open Dumping sebesar 94,1\%. Kondisi ini berbanding lurus kondisi sampah yang dikelola lebih banyak di TPA Open Dumping dan hal ini tidak jauh berbeda dengan negara-negara berkembang yang pengelolaan sampah masih dilakukan secara konvensional yakni sistem Landfill, sedangkan di negara maju telah menggunakan teknologi dalam mengelola sampah (UNEP, 2004). Menurut Barton Et al. (2008) bahwa TPA sanitary landfill tanpa penangkapan gas akan menghasilkan emisi GRK tertinggi (1.2 ton $\mathrm{CO}_{2}$ e per ton sampah), diikuti oleh TPA open dumping (0,74 ton $\mathrm{CO}_{2}$ e per ton sampah), TPA control landfill $\left(0,19\right.$ ton $\mathrm{CO}_{2}$ e per ton sampah). Prinsipnya adalah sesuai IPCC 2006 bahwa emisi $\mathrm{CH}_{4}$ dihasilkan paling banyak pada kondisi TPA open dumping dibandingkan TPA control landfill (Melissa Weitz, et al, 2008). Kondisi TPA yang sebagian besar merupakan sistem open dumping, kebanyakan bahan organik mengalami dekomposisi anaerobik yang menyebabkan dihasilkannya gas $\mathrm{CH}_{4}$ lebih banyak. (Suprihatin, dkk, 2008), (Sing SK, et al, 2016).

Terbentuknya gas $\mathrm{CH}_{4}$ dipengaruhi oleh beberapa faktor (Westlake,1990), (Komilis et al, 1999), antara lain.
a. Komposisi Sampah
Komposisi sampah pada negera berkembang sebagian besar berupa

sampah makanan dan taman, sedangkan negara maju, terutama Amerika Utara, memiliki kandungan kertas dan karton yang sangat tinggi. Komposisi sampah organik di Jawa Tengah yang terdiri atas sampah dapur $47,75 \%$, daun $8,99 \%$ dan kayu $4,63 \%$ akan berpengaruh pada pembentukan $\mathrm{CH}_{4}$ karena memiliki nilai DOC yang tinggi (IPCC 2006). Jenis sampah organik seperti sisa makanan/dapur, taman, kertas memiliki kandungan DOC lebih besar dari pada plastik, logam, kaca. Pada sampah organik umumnya mengandung selulosa 40$50 \%$, lignin $10-15 \%$, hemiselulosa $12 \%$ dan protein $4 \%$ pada berat kering yang dapat diubah menjadi $\mathrm{CH}_{4}$ melalui reaksi fisika, kimia dan biologis (Barlaz et al., 1989).

b. Kandungan air

Kandungan air akan berpengaruh pada proses pembusukan sebagai contoh hasil penelitian KLH pada tahun 2011 diperoleh kandungan air pada sampah makanan sebesar $41 \%$, taman sebesar 43\%, kertas sebesar 56\%, logam sebesar 0\%, kaca sebesar 8\%. Air pada sampah berfungsi sebagai media untuk merangsang pertumbuhan sel dan metabolisme, transportasi nutrisi di bakteri (Mehta et al. 2002). Kandungan air akan bergantung pada kadar air disampah sejak awal (DMC/ Dry Matter Content), tingkat infiltrasi dari sumber air permukaan dan air tanah, dan jumlah air yang dihasilkan sebagai hasil dekomposisi sampah itu sendiri.

c. Sistem Pengelolaan Sampah di TPA

Sistem pengelolaan sampah di TPA berdasarkan pedoman dari IPCC 2006 akan berpengaruh pada pembentukan $\mathrm{CH}_{4}$ (Daura et al,, 2014). Tipe TPA dapat diklasifikasikan sebagai berikut pada tabel 8. 
Tabel 8. Nilai MCF Pada TPA

\begin{tabular}{clc}
\hline No & \multicolumn{1}{c}{ Tipe TPA } & Nilai MCF \\
\hline 1 & TPA Sanitary Landfill & 1,0 \\
2 & TPA Control Landfill & 0,5 \\
3 & TPA Open Dumping $>5$ mtr (Unmanaged Deep) & 0,8 \\
4 & TPA Open Dumping $<$ mentr (Unmanaged Shallow) & 0,4 \\
\hline \multicolumn{2}{c}{ Sumber : IPCC 2006 }
\end{tabular}

TPA open dumping tipe unmanaged deep memiliki MCF lebih tinggi dibandingkan unmanaged shallow dan control landfill. Perlu diketahui bahwa TPA sanitary landfill belum ada di wilayah Jawa Tengah.

d. Tingkat Keasaman Sampah

Tingkat keasaman $(\mathrm{pH})$ sampah akan berpengaruh pada pembentukan $\mathrm{CH}_{4}$ dan $\mathrm{pH}$ optimal untuk pembentukan $\mathrm{CH}_{4}$ pada range 6,8-7,2. Produksi gas $\mathrm{CH}_{4}$ akan menurun secara drastis pada $\mathrm{pH}$ di bawah 6,5. Apabila sampah yang mengandung Bahan Berbahaya dan Beracun (B3) tercampur dengan sampah, maka produksi $\mathrm{CH}_{4}$ diperkirakan akan terhambat.

e. Temperatur

Salah satu bakteri yang berperan pada proses pembentukan gas $\mathrm{CH}_{4}$ adalah bakteri Methanogenik yang sangat dipengaruhi oleh temperatur dalam proses pembusukan. Tingkat produksi $\mathrm{CH}_{4}$ berlangsung optimal pada temperatur $50-60{ }^{\circ} \mathrm{C}$. Biasanya pada TPA dengan kondisi terbuka pada area yang cukup luas dan kondisi temperatur $25-40{ }^{\circ} \mathrm{C}$ cukup berlangsungnya pembentukan gas $\mathrm{CH}_{4}$.

Guna mengurangi emisi yang dihasilkan, maka perlu adanya aksi mitigasi pengelolaan sampah di TPA dengan dengan target pengurangan emisi s.d 2020. Aksi mitigasi akan dibagi menjadi 2 tahap yakni tahap I tahun 2010-2016 aksi mitigasi yang telah dilakukan di Kabupaten/Kota dan tahap II rencana aksi mitigasi tahun 2017-2020. Berdasarkan identifikasi di Kabupaten/Kota berikut aksi mitigasi yang telah dilakukan tahun 2010-2016 dan rencana penurunan emisi GRK tahun 20172020 sebagai berikut pada tabel 9.

Tabel 9. Rencana Aksi Penurunan Emisi GRK

\begin{tabular}{cccccc}
\hline Tahun & $\begin{array}{c}\text { Jumlah Kab/ } \\
\text { Kota }\end{array}$ & $\begin{array}{c}\text { Sampah } \\
\text { yang dikurangi } \\
(\mathbf{G g} / \mathbf{t h n})\end{array}$ & $\begin{array}{c}\text { Penurunan } \\
\text { Emisi }\left(\mathbf{C O}_{\mathbf{2}} \mathbf{e}\right) \\
\mathbf{G g} / \mathbf{t h n}\end{array}$ & $\begin{array}{c}\text { Penurunan Emisi } \\
\text { Akumulatif s.d. } \\
\mathbf{2 0 2 0}(\mathbf{C O} \mathbf{e}) \mathbf{G g} / \\
\text { thn }\end{array}$ & $\begin{array}{c}\text { Penurunan } \\
\text { Emisi GRK } \\
(\mathbf{\%})\end{array}$ \\
\hline 2010 & 0 & 0,00 & 0 & 0 & 0,00 \\
2011 & 2 & 5,13 & 1,42 & 1,42 & 0,09 \\
2012 & 3 & 3,13 & 0,87 & 2,30 & 0,13 \\
2013 & 3 & 3,13 & 0,87 & 3,17 & 0,18 \\
2014 & 0 & 0,00 & 0,00 & 3,17 & 0,18 \\
2015 & 1 & 5,11 & 1,42 & 4,59 & 0,25 \\
2016 & 1 & 42,15 & 11,73 & 16,33 & 0,89 \\
2017 & 8 & 138,57 & 38,57 & 54,90 & 2,94 \\
2018 & 9 & 181,66 & 50,57 & 105,48 & 5,56 \\
2019 & 10 & 185,83 & 51,73 & 157,21 & 8,18 \\
2020 & 4 & 89,92 & 25,03 & 182,24 & 9,35 \\
\hline
\end{tabular}

Sumber : Hasil perhitungan, 2017

Berdasarkan tabel di atas, pembangunan TPA hanya sebanyak 10 unit TPA. Upaya yang dilakukan di Kabupaten/Kota sampai dengan tahun 2016 s.d. tahun 2016 hanya mampu menurunkan 
emisi 0,89 \%. Berdasar kuisoner tahap 2 untuk rencana kegiatan dalam pengurangan emisi di TPA dengan hasil 31 Kabupaten/Kota akan berperan menurunkan emisi GRK sektor sampah domestik. Target penurunan emisi s.d. 2020 diprediksi sebesar 9,35\% atau 182,245 $\mathrm{Gg} \mathrm{CO}_{2}$ e. Keterbatasan anggaran, pemilihan lahan, ketidaksesuaian Rencana Tata Ruang Wilayah (RTRW) dan faktor sosial menyebabkan pengelolaan sampah tidak berlangsung dengan optimal.

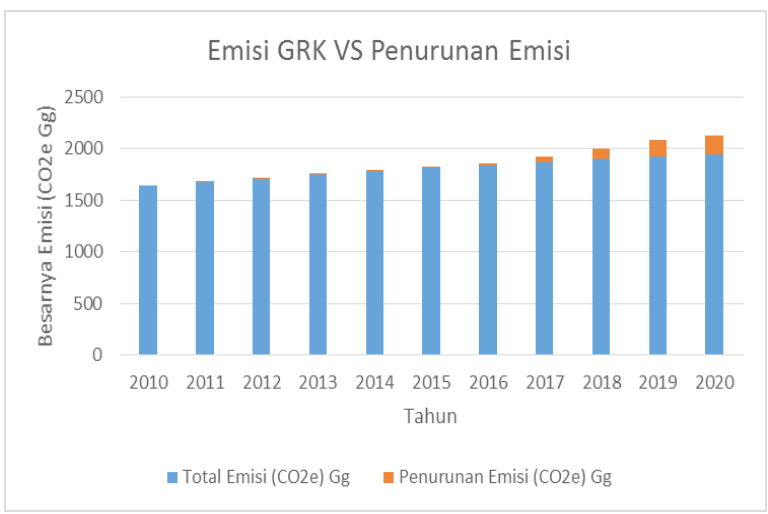

Grafik 4. Perbandingan Besarnya Emisi dengan Rencana Aksi Mitigasi

Namun permasalahan sosial yang menjadi faktor utama dimana penolakan keberadaan TPA lama maupun calon TPA oleh masyarakat sekitar berkenaan dengan sebab yang membahayakan kesehatan, keselamatan, berkurangnya kenyamanan (Mahyudin, 2017). Menurut Melissa Weitz, Et al (2008) Aksi penurunan emisi lainnya yang dapat dilakukan adalah mengoptimalkan pengelolaan sampah pada sumbernya yakni prinsip 3R (Reduce, Reuse, Recycle) baik yang dilakukan oleh Pemerintah maupun masyarakat. Pada jurnal ini penulis hanya fokus perhitungan emisi dan pengurangan emisi terhadap sampah yang dikelola di TPA. Berikut grafik besarnya emisi tahun 2010-2020 sebelum ada aksi mitigasi (warna biru) dan besarnya emisi yang dapat diturunkan (warna orange).

\section{Simpulan}

1. Pengelolaan sampah pada 57 TPA di Jawa Tengah sebagian besar masih dalam kondisi Open dumping/unmanaged dengan emisi yang dihasilkan sebesar $94,10 \%$ sedangkan control landfill sebesar 5,90\%

2. Jenis pengelolaan sampah dengan control landfill tahun 2010-2020 diperkirakan hanya mampu menurunkan emisi sebesar $9,35 \%$.

\section{Ucapan Terima Kasih}

Ucapan terima kasih disampaikan kepada Bupati/Walikota 35 Kabupaten/Kota di Jawa Tengah, Kepala Instansi Lingkungan Hidup 35 Kabupaten/Kota, rekan-rekan staf Instansi Lingkungan Hidup Kabupaten/Kota yang telah membantu dalam pelaksanaan penelitian ini.

\section{Daftar Pustaka}

Barlaz, M.A., Schaefer, D.M., Ham, R.K., 1989. Bacterial population development and chemical characteristics of refuse decomposition in a simulated sanitary landfill. Applied and Environmental Microbiology 55 (1), 55-65

Daura, L.A, Enaburekhan,J, Rufai, A.I, 2014. Estimation of Methane gas Emission from Solid Waste disposal sites in Kano, Nigeria. International Journal of Scientific \& Engineering Research, Volume 5, Issue 10, October-2014

Hezhong, T., Jiajia , G., Long, L., Cuangyong, Z., Peipei, Q., 2013. Atmospheric Pollution Problems and Control Proposals Associated with Solid Waste Management in China

Karagiannidis A, Tsatsarelis T, Moussiopoulus N, 2007. Estimation of methane Potential From Landfill Gas of The New Hellenic Sanitary landfills. Laboratory of Heat Transfer and Environmental Engineering, Department of Mechanical Engineering, Aristotle University. Thessaloniki, Greece

KLHK, 2016. Perubahan Iklim, Perjanjian Paris, dan Nationally Determined Contribution. Direktorat Jenderal Pengendalian Perubahan Iklim. Jakarta 
Komilis, D.P., Harn, R.K., Stegmann, R., 1999. The effect of landfill design and operation practices on waste degradation behaviour: a review. Waste Management and Research 17, 20-26

Kyiv, 2004. Inventory of Methane Emissions in the Solid Waste Sector of Ukraine. Agency for Rational Energy Use and Ecology (Ukraine)

Mahyudin, P.R., 2017. Kajian Permasalahan Pengelolaan Sampah dan Dampak Lingkungan di Tempat Pemrosesan Akhir (TPA). Jukung Jurnal Teknik Lingkungan, 3 (1) : 66-74, 2017

Mark Orlic and Tom Kerr (1996). A Guide for Methane Mitigation Projects. Gas-to-Energy at Landfills and Open Dumps. Draft. U.S. Environmental Protection Agency Office of Air and Radiation. January

Mehta, R., Barlaz, M.A., Yazdani, R., Augenstein, D., Bryars, M., Sinderson, L., 2002. Refuse decomposition in the presence and absence of leachate recirculation. J. Environ. Eng. 128 (3), 228-236

Melissa, W., Coburn, B.J., Salinas,E., 2008. Estimating National Landfill Methane Emissions: An Application of the 2006 Intergovernmental Panel on Climate Change Waste Model in Panama. Journal of the Air \& Waste Management Association. Volume 58 May 2008

P.B.Vyas, 2011. Municipal Solid Waste Management At India. Sigma Institute of Engineering Bakrol, Vadodara, India. Jr. of Industrial Pollution Control 27(1)(2011) pp 79-81

Sing SK, Anunay G, Rohit G, Shivangi G, Vipul V, 2016. Greenhouse Gas Emisions From Landfill : A Case of NCT of Delhi, India

Solomon S, Qin D, Manning M, Chen Z, Marquis M, et al. (2007) Climate Change 2007: The Physical Science Basis, IPCC Fourth Assessment Report

Suprihatin, Indrasti, S.W, Romli, M., 2008. Potensi Penurunan Emisi Gas Rumah Kaca Melalui Pengomposan Sampah. Departemen Teknologi Industri Pertanian, Fakultas Teknologi Pertanian - IPB. J. Tek. Ind. Pert. Vol. 18(1), 53-59

UNEP-United Nations Environment Programme, 2004. Waste management planning - An environmentally sound approach for sustainable urban waste management, An introductory guide for decision-makers, Report prepared by the Division of Technology, Industry and Economics, Integrative management series No. 6, Report downloaded from (Dec 2010)

Wangyao, K., Towprayoon, S., Chiemchaisri, C., Gheewala, S.H., Nopharatana, A., 2009. Application of the IPCC waste model to solid waste disposal sites in tropical countries: case study of Thailand. Environmental Monitoring and Assessment 164, 249-261

Weitz, M., Coburn, J.B., Salinas, E., 2008. Estimating national landfill methane emissions: an application of the 2006 Intergovernmental Panel on Climate Change waste model in Panama. Journal of the Air \& Waste Management Association 58, 636-640

Westlake K. (1990) "Landfill Microbiology," Proceedings of the International Conference Landfill Gas: Energy and Environment '90, Bournemouth, U.K 